Article

\title{
Consumption of Free Chlorine in an Aqueduct Scheme with Low Protection: Case Study of the New Aqueduct Simbrivio-Castelli (NASC), Italy
}

\author{
Vincenzo Torretta ${ }^{1,+}{ }^{(D}$, Athanasia K. Tolkou ${ }^{2,+}$, Ioannis A. Katsoyiannis ${ }^{2,+}$, \\ Athanasios Katsoyiannis ${ }^{3,+}$, Ettore Trulli ${ }^{4,+}$ (D), Elena Magaril ${ }^{5,+}$ (iD and \\ Elena Cristina Rada $1,6, *,+$ (iD) \\ 1 Department of Theoretical and Applied Sciences, Insubria University of Varese, via G.B. Vico, 46, \\ I-21100 Varese, Italy; vincenzo.torretta@uninsubria.it \\ 2 Laboratory of Chemical and Environmental Technology, Department of Chemistry, \\ Aristotle University of Thessaloniki, GR-54124 Thessaloniki, Greece; katsogia@chem.auth.gr (A.K.T.); \\ tolkatha@chem.auth.gr (I.A.K.) \\ 3 Norwegian Institute for Air Research (NILU)_FRAM High North Research Centre on Climate and the \\ Environment, Hjalmar Johansens gt. 14 NO, 9296 Tromso, Norway; athanasios.katsogiannis@gmail.com \\ 4 Department of Engineering and Environmental Physics, University of Basilicata, via dell'Ateneo Lucano, 10, \\ I-85100 Potenza, Italy; ettore.trulli@unibas.it \\ 5 Department of Environmental Economics, Ural Federal University, Mira Str., 19, Ekaterinburg 620002, \\ Russia; magaril67@mail.ru \\ 6 Department of Civil, Environmental and Mechanical Engineering, University of Trento, via Mesiano, 77, \\ I-38123 Trento, Italy \\ * Correspondence: elena.rada@unitn.it \\ + These authors contributed equally to this work.
}

Received: 19 November 2017; Accepted: 26 January 2018; Published: 30 January 2018

\begin{abstract}
The safety of high quality drinking water supply relies on the quantities to be delivered, on the complexity of the water supply systems, and on the widespread phenomena of the contamination of water bodies. These parameters indicate the need for the development of an application that will allow the quick acquisition of data on strategic management. This is requires both the analysis of factors related to the hydraulic operation of the plants and the characteristics of water quality. The present paper aims to evaluate the use of models that predict data for water quality in a distribution system. The assessment is made in order to consider the use of the model as a support tool for the management system of a supply network and to optimize the quality of the provided service. The improvement of the control system related to the operations of disinfection, in particular, in the case of long pipelines, is absolutely mandatory in order to ensure the safety of public health and respect for the environment at high levels.
\end{abstract}

Keywords: free chlorine; water supply; distribution systems; model prediction

\section{Introduction}

In water supply network systems, when water is supplied from poorly protected catchment areas or where a proper treatment phase is not provided, periodic or accidental degradation of drinking water quality is often observed. The monitoring of water quality is therefore intended to play a proactive role. The spread of systems based on online analytical techniques for the measurement of the quality of different piping system parameters, combined with efficient computational models, can enable the prediction of the characteristics of the water in a fast and accurate way and thus provide data not only to circumvent the supply of water of low quality but, more importantly, improve the 
efficiency of purification techniques. Conventional water-quality event detection methods monitor online events indirectly by detecting physical and chemical water-quality parameters such as $\mathrm{pH}$, chlorine, conductivity, oxygen-reduction potential, and turbidity or unconventional ones such as volatile organic compounds (VOCs) [1-6].

Chlorine, used in various forms as free chlorine and combined chlorine, is widely used in the disinfection of natural waters, due to higher oxidizing potential downstream of disinfection processes that use free chlorine, within the supply and distribution networks and/or in tanks or reservoirs [7]. Unintended reduction in the concentration of the active residual disinfectant is sometimes observed and can be attributed to several phenomena, like, for example, the reaction of residual chlorine with natural organic matter from contaminated water entering the distribution network [8]. The performance of free chlorine is typically an indication of unsanitary conditions inside the piping. Therefore, the analysis of the concentration of free chlorine can be used as a control function of the water quality, or can be considered as a management function, whereas its systematic determination can allow for the recognition of the degradation processes taking place in the network and provide information to set the disinfection process [9]. The simulation models to estimate the concentration of chlorine in water supply networks have been developed based on this criterion $[7,10]$. The present article shows the results of a survey conducted to analyze the changes in concentration of chlorine in the water transported in a pattern characterized by long water supply pipelines. The need for such work is evident above all in situations where, as a result of long pipelines used in a drinking water supply system, there are not sufficient water quality control systems-not just for some microbiological pollutant(s), but for the microbiota derived from the operations of disinfection. This approach is fundamental in order to guarantee high levels of protection of public health.

\section{Issues Related to the Use of Chlorine in Water Supply Networks}

The quality of the water distributed through the supply network is influenced by different factors and the transformation processes that occur during the treatment process and the distribution in the piping $[8,11]$.

The following issues have great interest:

(a) the consumption of residual disinfectant in the network;

(b) the formation of toxic substances from the reaction of the oxidants used in the disinfection;

(c) the establishment of microbial growth processes in the network.

\subsection{Consumption of Free Chlorine in the Network}

The presence of a residual concentration of free chlorine (hypochlorous acid $(\mathrm{HOCl})$ and ion hypochlorite $\left.\left(\mathrm{OCl}^{-}\right)\right)$in treated water is indicative of an efficient disinfection (i.e., inefficient destruction of pathogenic microorganisms). The technical literature indicates that concentration values of residual free chlorine in the range $0.2-0.5 \mathrm{ppm}$ ensure a good level of protection [12]. Following conditions of quality degradation in the water transported downstream of the treatment, a reduction in the activity of the disinfectant (chlorine) decay may occur. This is due to different reactions that lead to the reduction of free forms of chlorine from both chemical and biological transformations of material present in suspended form in the liquid phase or immobilized on the solid-liquid interface in contact with the walls of the pipes and tanks, interfering with the fouling and corrosion processes.

The reaction of chlorine in water follows the reaction shown below:

$$
\mathrm{Cl}_{2}+\mathrm{H}_{2} \mathrm{O} \rightarrow \mathrm{HOCl}+\mathrm{HCl}
$$

Hydrochloric acid dissociates in turn to form hydrogen and chloride ions

$$
\mathrm{HCl} \rightarrow \mathrm{H}^{+}+\mathrm{Cl}^{-}
$$


Hypochlorous acid, however, dissociates only partially

$$
\mathrm{HOCl} \leftrightarrow \mathrm{H}^{+}+\mathrm{OCl}^{-}
$$

Several studies have been conducted to evaluate the factors that influence the process of consumption of free chlorine [13-15]. A non-negligible influence of corrosion phenomena, in particular in pipes of cast iron, was also detected [16].

\subsection{Final Products of Chlorine Reactions}

The oxidation of the soluble natural organic fraction (NOM) present in the water favors the formation of organohalogen compounds. Chlorine can effectively convert humic substances to trihalomethanes (THMs), and other oxidation by-products of organohalogen compounds under the reaction conditions which occur in the liquid phase within the treatment systems [17].

In order to identify the organochlorine compounds produced in the disinfection phase, certain parameters, with which different fractions of halogenated compounds are detected, have been introduced. The main ones are the total organic halides (TOX), the adsorbable organic halides (AOX), and the extractable organic halides (EOXs). The choice is made on the basis of the possibility of evaluating the parameter, its correspondence to the physical phenomenon that is to be analyzed, and the ease of repeating the analysis in other contexts [18].

\subsection{Microbial Growth}

All types of waters, even those that come from deep aquifers practically well protected, contain some microorganisms, which continuously grow, even at relatively low temperatures [15]. Low levels of dissolved oxygen (DO) and significant amounts of soluble iron and sulfur compounds were found in some groundwaters [19]. These conditions are favorable to the growth of unwanted bacterial species, such as iron bacteria and sulfur bacteria $[20,21]$.

The microorganisms already present in the water introduced into the supply network, even in small amounts, can promote the phenomena of microbial regrowth in pipes when the water has a sufficient content of organic substrate and nutrients (e.g., phosphorus), and the microorganisms are in the presence of $\mathrm{DO}$, and when there are the thermal conditions stimulating bacterial replication [22,23]. These conditions generally are present in all types of pipes [24].

In order to assess the presence of organic matter in drinking water treatment units and water supply systems that can be metabolized by microorganisms, Biodegradable Dissolved Organic Carbon (BDOC) and the Assimilable Organic Carbon (AOC) were used as indicators. Even if other possible alternatives might have been available, these represented the simple options that could be used in order to give an operative approach to the research. The AOC is the fraction of the organic carbon quickly usable by microorganisms and is generally a fraction of the total organic carbon (TOC) in variable percentage values between $0.1 \%$ and $9 \%$ [25]. The BDOC is the fraction of the Dissolved Organic Carbon (DOC) which can be metabolized by bacteria within a period of a few days to few months, which is of particular importance for drinking water, as it can be the starting point of bacteria regrowth leading to the development of undesirable higher organisms [26]. The results of a survey conducted in the United States have shown that the ratio between BDOC and DOC in water distribution networks can have values greater than $0.1 \mathrm{mg} / \mathrm{L}$. In river water, that value may increase up to $0.5 \mathrm{mg} / \mathrm{L}[27,28]$.

\section{Data Analysis Section-Modeling of the Chlorine Consumption with Semi-Empirical Methods}

The calculation models that simulate chlorine decay are valuable tools for the management of chlorine residuals and for reproducing the evolution of quality parameters in the network. They can assist water network managers in identifying the correct action to be pursued [29-34]. The models typically operate with two distinct modules: the first provides the calculation of characteristic quantities 
of the hydraulic motion processes and the second one, on the basis of the reconstruction of the velocity field, analyzes the changes in the concentrations of contaminants, taking into account diffusive phenomena, mixing, and decay. In particular, the process of propagation of contaminants is represented on the basis of a scheme consisting of elements or volumetric finite segments in which the pipeline was divided or analyzing calculation blocks of variable sizes that move along the pipeline.

EPANET is one of the most widely used computing models $[35,36]$ and this is the reason why this software was chosen. It is a software that enables the modelling of multiple constituents throughout the water distribution system (WDS) [37]. The chemical reactions between the constituents are described by differential-algebraic equations and are solved by numerical methods. In the present study, the consumption of the simulated substance, i.e., chlorine, in the network is described through the development of two processes that develop in the liquid phase and at the liquid-solid contact with the inner walls of the pipeline. The reaction rate is set with a first-order model, which assumes that the chlorine concentration decreases exponentially:

$$
\frac{\mathrm{dC}(\mathrm{t})}{\mathrm{dt}}=-\mathrm{k}_{\mathrm{b}} \cdot \mathrm{C}(\mathrm{t})
$$

where:

C, chlorine concentration;

$\mathrm{t}$, time;

$\mathrm{k}_{\mathrm{b}}$ constant reaction rate, in $\mathrm{h}^{-1}$ or day ${ }^{-1}$.

The $k_{b}$ values were estimated for distribution networks [22,38]: the values vary from $0.01 \mathrm{~h}^{-1}$ to $0.3 \mathrm{~h}^{-1}$. For the determination of $\mathrm{k}_{\mathrm{b}}$ as a function of temperature and concentration of the organic carbon, Kiene et al. (1998) [38] proposed the following experimental procedure: Temperature between $5^{\circ} \mathrm{C}$ and $25^{\circ} \mathrm{C}$ and TOC concentration between 1 and $3 \mathrm{mgC} \mathrm{L}{ }^{-1}$ :

$$
\mathrm{k}_{\mathrm{b}}=a \mathrm{C}_{\mathrm{TOC}} \exp (-b / \mathrm{T})
$$

where:

$\mathrm{T}$, temperature in Kelvin degrees;

$\mathrm{C}_{\mathrm{TOC}}$, concentration of TOC in $\mathrm{mgC} \mathrm{L}^{-1}$;

$a$ and $b$, coefficients: $a=1.8 \times 10^{6}$ and $b=6050$.

The kinetics of the reactions that occur at the solid-liquid interface of the walls of the pipes are influenced by the specific surface and the process of mass transfer between the liquid medium and the solid phase [39]. The consumption of chlorine on the walls of the duct is determined by applying first-order kinetics. The rate of reaction is expressed by the following relationship:

$$
\frac{\mathrm{dC}(\mathrm{t})}{\mathrm{dt}}=-\frac{2}{\mathrm{R}} \cdot\left(\frac{\mathrm{k}_{\mathrm{w}} \cdot \mathrm{k}_{\mathrm{f}}}{\mathrm{k}_{\mathrm{w}}+\mathrm{k}_{\mathrm{f}}}\right) \cdot \mathrm{C}(\mathrm{t})
$$

where:

$\mathrm{R}$, radius of the pipe;

$\mathrm{k}_{\mathrm{w}}$, constant reaction rate to the wall [length]/[time],

$\mathrm{k}_{\mathrm{f}}$, mass transfer coefficient, [length]/[time].

The $\mathrm{k}_{\mathrm{w}}$ value was determined according to pipe roughness by using the following equation:

$$
\mathrm{k}_{\mathrm{w}}=\mathrm{F} / \mathrm{C}
$$

where:

C, is the roughness coefficient used in the Hazen-Williams formula,

$\mathrm{F}$, is a calculation coefficient. 
Applying $\mathrm{F}$ values between 1.5 and $15, \mathrm{k}_{\mathrm{w}}$ varied between 0.001 and $0.01 \mathrm{~m} \mathrm{day}^{-1}$. The determination of $\mathrm{k}_{\mathrm{f}}$ is carried out in accordance to the characteristics of the analyzed species, by means of the reactivity conditions, the molecular diffusivity, and the hydrodynamic conditions of the flow, using the Reynolds number [40].

\section{Materials and Methods}

\subsection{Characterization of the Distribution Network for Water Supply}

The study aims to analyze the process of consumption of free chlorine in the New Aqueduct Simbrivio-Castelli (NASC), which supplies drinking water to about sixty (60) municipalities and three industrial areas in an area located in Central Italy, serving a population of about 350,000 inhabitants. Figure 1 shows the quality index of those areas, by comparing the water quality data.

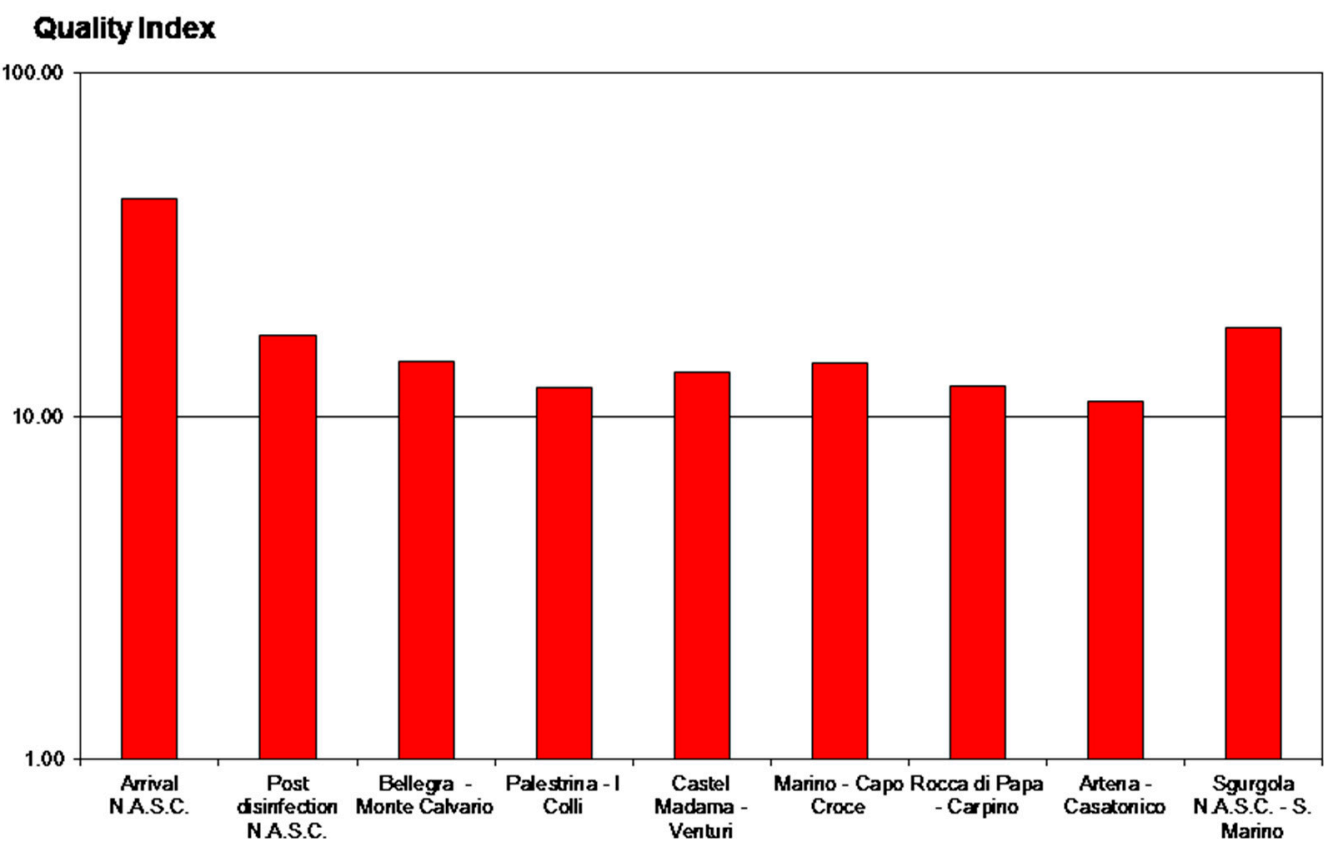

Figure 1. Quality index of the supply network located in Central Italy.

The flow conveyed to the distribution centers is about $0.7 \mathrm{~m}^{3} \mathrm{~s}^{-1}$. The pipelines extend for about $350 \mathrm{~km}$; they are built mostly from steel. In some places there are pipelines made of gray and ductile iron. The diameters range from ND50 to ND800 (nominal diameter equal to 50 and $800 \mathrm{~mm}$, respectively). The supply of the aqueduct, originally secured by groups of springs, has been integrated with the waters from other springs and groundwater sources.

The operative scheme is briefly described in the following points:

1. the water from the different sources is mixed in a longitudinal tank, called a "hydraulic gallery"; in this basin, which is the source of supply pipelines, sodium hypochlorite is added as a disinfection agent;

2. the main duct branches into numerous secondary pipelines.

The water scheme has been characterized according to its different elements: tanks, dividers, pipelines, lifting equipment. Pipes were characterized based upon their construction material, year of commissioning, length, and diameter. The data relating to the management of the water in the years 2008-2010 were collected with the following information considered: 
1. flows from the different sources;

2. days of interruption of the supply service;

3. repair of hydraulic losses occurred on pipes;

4. interruptions in the disinfection procedure.

\subsection{Collection of Data on Water Quality}

The monitoring of water quality was conducted in 34 sampling stations.

The analyses relating to the water quality refer to a time period of two years, in which 1117 samples were analyzed. The samples were divided into the following classes:

(a) aqueduct water supply (springs and wells);

(b) water procured to the aqueduct network;

(c) disinfected water supplied to the supply network;

(d) water transported by the supply network to the consumers.

The methods of analysis comply with the Unichim Manual, which describes the water analysis procedures [41]. The technical standards adopted are those used as reference by the State where the case study was conducted.

\subsection{Method of Processing Data}

In the first phase, the water quality time series data (temperature, $\mathrm{pH}$, nitrates, turbidity, Kubel oxidability, free chlorine, total and fecal coliforms, fecal streptococci colonies on agar at $22{ }^{\circ} \mathrm{C}$ and $36^{\circ} \mathrm{C}$ ) were reconstructed and the main statistical parameters were calculated (Figures 2 and 3).

In the second phase, a monitoring network, constituted by a reduced number of sampling stations, was selected, in accordance with appropriate access to the sampling points. On the basis of availability and significance of the data, and taking into account the location along one of the main pipelines and the distance between the stations, in the order of $15-25 \mathrm{~km}$, seven sampling stations were selected.

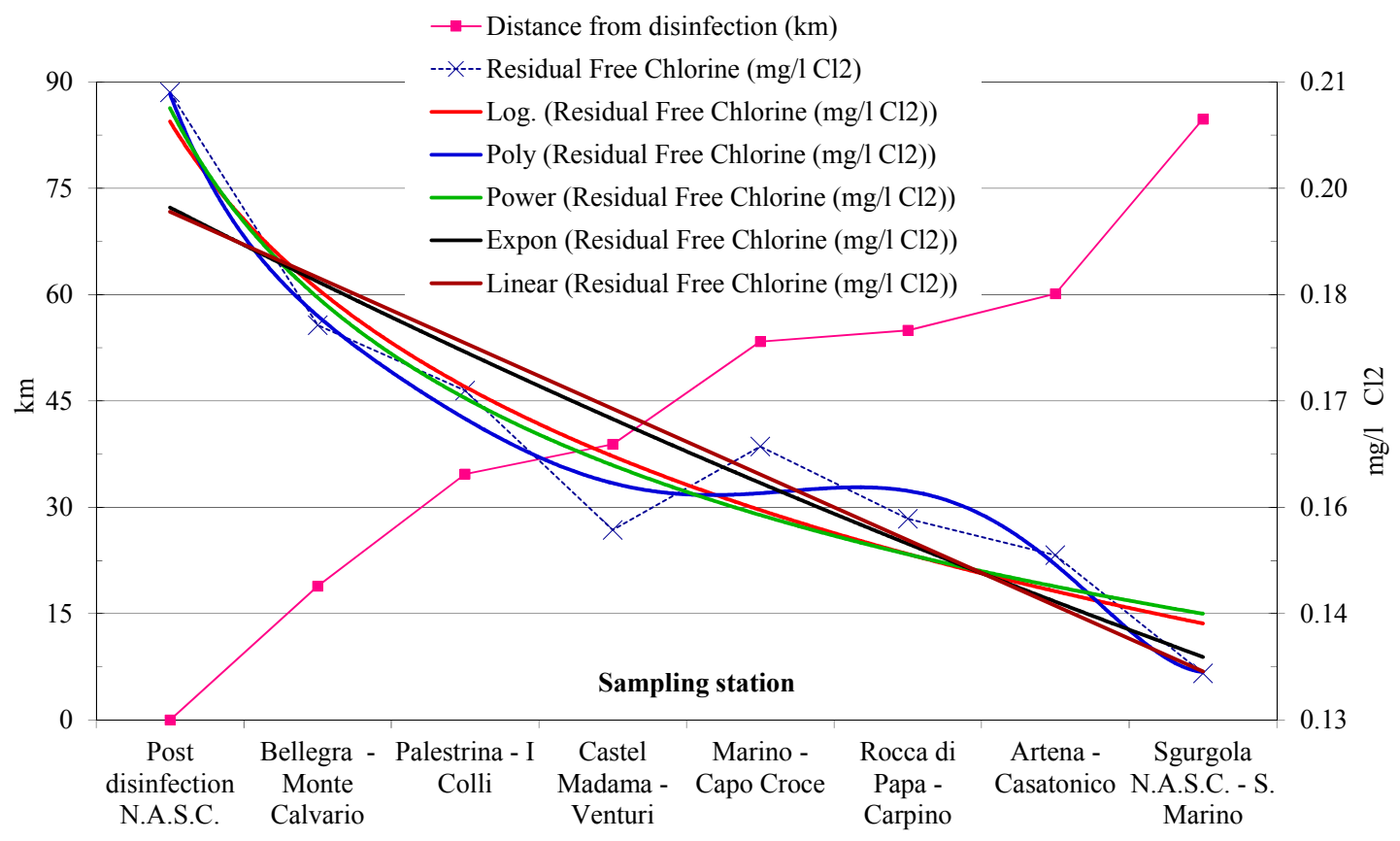

Figure 2. Water quality (temperature, $\mathrm{pH}$, nitrates, turbidity, Kubel oxidability, free chlorine, total and fecal coliforms, fecal streptococci colonies on agar at $22{ }^{\circ} \mathrm{C}$ and $36{ }^{\circ} \mathrm{C}$ ) observed in sampling stations (one after the other). 


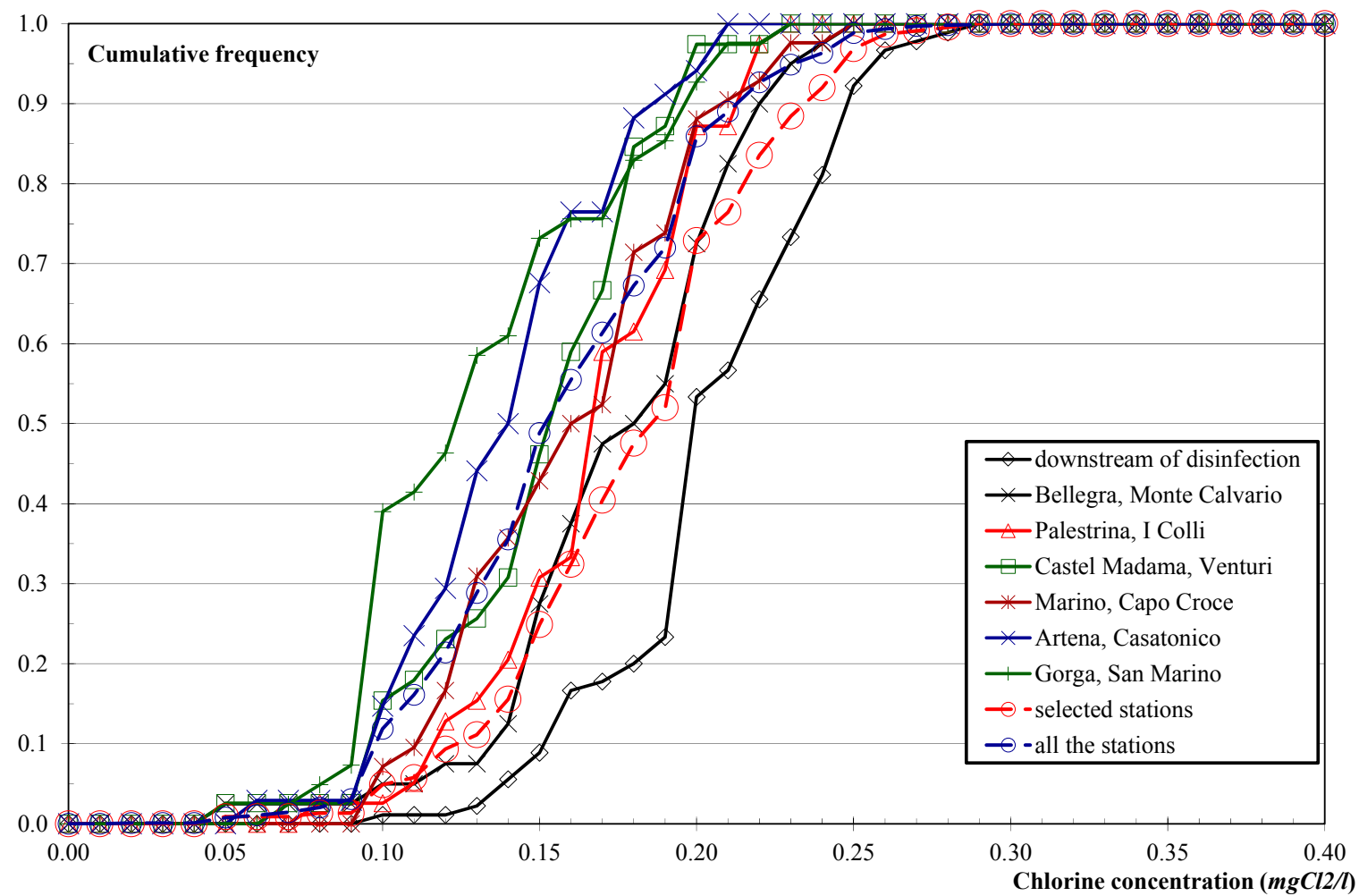

Figure 3. Cumulative frequency of the chlorine concentration $\left(\mathrm{Mg} \mathrm{Cl}_{2} / \mathrm{L}\right)$ observed in sampling stations.

\section{Results}

\subsection{Processing of Free Chlorine Data}

The data were measured over two years (June 2010-June 2012). Table 1 shows the values of the main statistical parameters, and Figure 4 shows the trends of chlorine concentrations and ccumulative trends observed in the survey period in the sampling stations.

Table 1. Number of samples and statistical parameters related to the observed concentration of free chlorine.

\begin{tabular}{cccccccccc}
\hline Sampling Stations & Median & $\mathbf{7 0 \%}$ & $\mathbf{8 0 \%}$ & $\mathbf{9 0 \%}$ & Min. & Max. & $\begin{array}{c}\text { Total } \\
\text { Average }\end{array}$ & $\begin{array}{c}\text { Yearly } \\
\text { Number of } \\
\text { Samples }\end{array}$ & $\begin{array}{c}\text { Number of } \\
\text { Samples }\end{array}$ \\
\hline $\begin{array}{c}\text { Trevi, Hydraulic gallery, } \\
\text { downstream of disinfection } \\
\text { km 0 + 000 m }\end{array}$ & 0.2 & 0.23 & 0.24 & 0.25 & 0.1 & 0.29 & 0.21 & 90 & 41.5 \\
\hline $\begin{array}{c}\text { Bellegra, Monte Calvario } \\
\text { km 18.450 }\end{array}$ & 0.19 & 0.2 & 0.21 & 0.22 & 0.05 & 0.25 & 0.18 & 40 & 18.5 \\
\hline $\begin{array}{c}\text { Palestrina, I Colli } \\
\text { km 32.805 }\end{array}$ & 0.17 & 0.2 & 0.2 & 0.22 & 0.08 & 0.23 & 0.17 & 39 & 18 \\
\hline $\begin{array}{c}\text { Castel Madama, Venturi } \\
\text { km 32.750 }\end{array}$ & 0.16 & 0.18 & 0.18 & 0.2 & 0.05 & 0.23 & 0.15 & 39 & 18 \\
\hline
\end{tabular}


Table 1. Cont.

\begin{tabular}{ccccccccccc}
\hline Sampling Stations & Median & $\mathbf{7 0} \%$ & $\mathbf{8 0} \%$ & $\mathbf{9 0} \%$ & Min. & Max. & Average & $\begin{array}{c}\text { Total } \\
\text { Number of } \\
\text { Samples }\end{array}$ & $\begin{array}{c}\text { Yearly } \\
\text { Number of } \\
\text { Samples }\end{array}$ \\
\hline $\begin{array}{c}\text { Marino, Capo Croce } \\
\text { km 55.019 }\end{array}$ & 0.17 & 0.18 & 0.2 & 0.21 & 0.1 & 0.25 & 0.16 & 42 & 19.4 \\
\hline $\begin{array}{c}\text { Artena, Casotonico } \\
\text { km 58.047 }\end{array}$ & 0.15 & 0.16 & 0.18 & 0.19 & 0.06 & 0.21 & 0.14 & 34 & 15.9 \\
\hline $\begin{array}{c}\text { Gorga, San Marino } \\
\text { km 77.224 }\end{array}$ & 0.13 & 0.15 & 0.18 & 0.2 & 0.07 & 0.23 & 0.14 & 41 & 18.9 \\
\hline
\end{tabular}

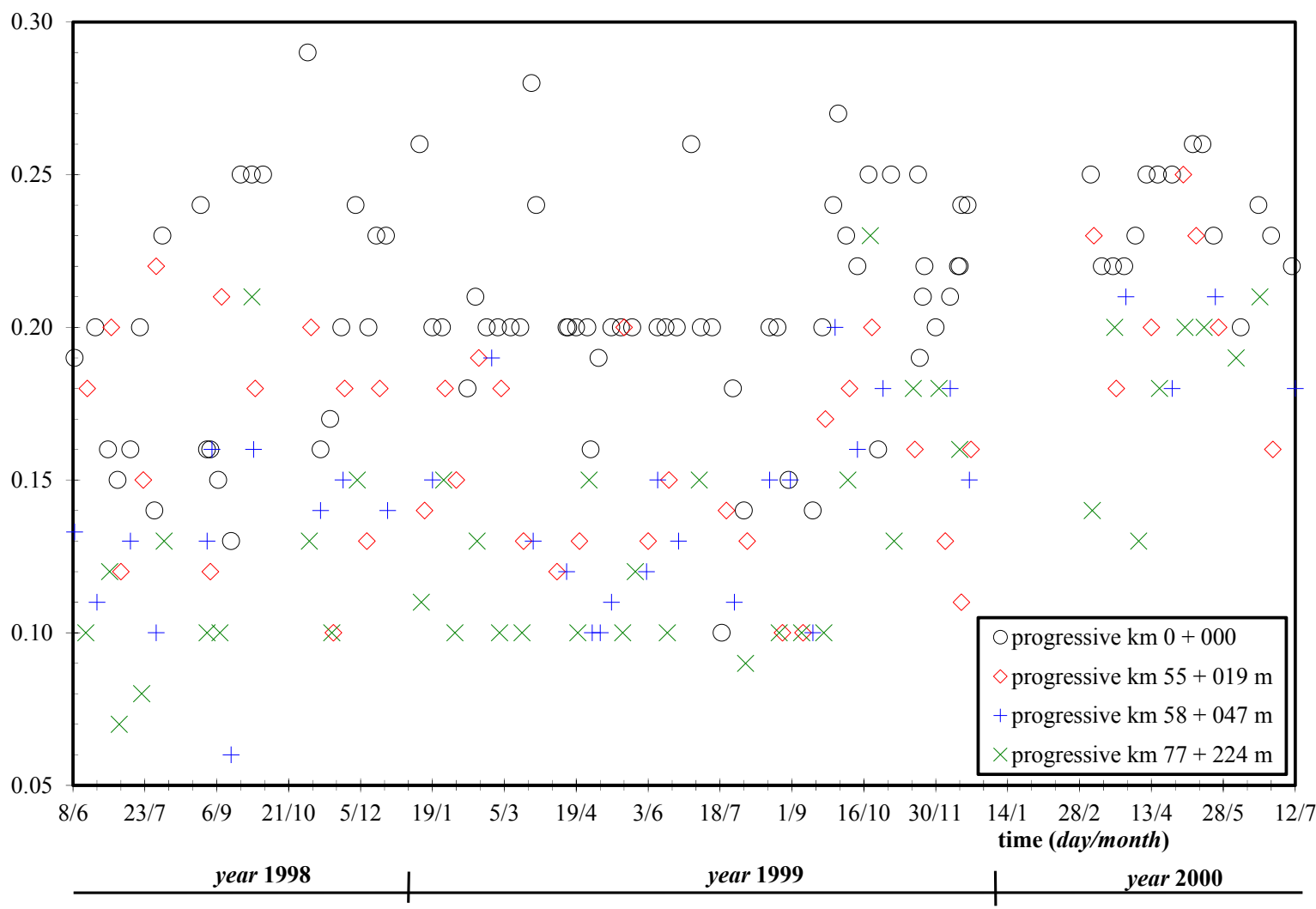

Figure 4. Trend of the chlorine concentration observed in sampling stations (up: progressive $\mathrm{km} 0$, km 18.45, km 32.855; down: progressive km 0, km 55.019, km 58.047).

\subsection{Simulations with EPANET Model}

The last phase of the survey consisted of the reconstruction of the field of free chlorine concentration using the 2.0 EPANET model [35]. The simulations were carried out considering an ordinary hydraulic regime, in stationary conditions, inside the supply network [42-44]. The hydraulic layout is constituted by: two tanks working with constant hydraulic load (tanks receiving water from springs and wells); four tanks in variable hydraulic load (hydraulic gallery and hydraulic dividers); 107 nodes (dividers in pressure and flow delivery points); 105 pipes with an internal diameter ranging between $50 \mathrm{~mm}$ to $800 \mathrm{~mm}$; 11 water pumping systems. The delivered flow rate was set equal to the annual average value.

The pressure losses were calculated with the formula of Hazen-Williams by varying the coefficients of roughness between 130 and 135 for cast-iron pipes and between 140 and 150 for steel pipelines [35]. The flow rates delivered to the nodes were set equal to the annual average values of flow at the delivery 
points of municipal and cooperatives utilities. The trend of the concentration of chlorine was studied by applying a first-order kinetic model for the reactions in the liquid medium and at the walls of the pipe. The values of $k_{b}$ were made to vary between 0.1 and 0.9 day $^{-1}$. The values of the coefficient $\mathrm{k}_{\mathrm{w}}$ were determined according to the roughness of the pipeline and $\mathrm{k}_{\mathrm{w}}$ ranged between 0.001 and $0.01 \mathrm{~m} \mathrm{day}^{-1}$. Table 2 shows the hydraulic residence times in the network, calculated in the sampling sections. Figure 5 illustrates the comparison between the chlorine concentration values calculated in the sampling sections with the model compared with the statistical variables related to the measured data. The model provides a good fit and a good capacity to describe the degradative processes active in the aqueduct, in particular in hydraulic steady conditions.

Table 2. Simulation results: hydraulic residence times in the network calculated in the sampling stations.

\begin{tabular}{ccccc}
\hline Sampling Station & Chainage & $\begin{array}{c}\text { Hydraulic } \\
\text { Residence Time }\end{array}$ & $\begin{array}{c}\text { Dimensionless } \\
\text { Residence Time, } \mathbf{t}\end{array}$ & Mean Velocity \\
\cline { 2 - 5 } & $\mathbf{m}$ & day & day day & m s $^{\mathbf{- 1}}$ \\
\hline Trevi, downstream to disinfection & 0 & 0.000 & 0.000 & $=$ \\
Bellegra, Monte Calvario & 18.450 & 0.153 & 0.189 & 1.400 \\
Monte Castellone & 20.900 & 0.174 & 0.216 & 1.389 \\
Palestrina, I Colli & 32.855 & 0.263 & 0.326 & 1.446 \\
Castel Madama & 36.750 & 0.295 & 0.366 & 1.442 \\
Marino, Capo Croce & 55.019 & 0.485 & 0.601 & 1.233 \\
Artena, Casatonico & 58.047 & 0.545 & 0.676 & 1.108 \\
Gorga, San Marino & 77.224 & 0.807 & 1.000 & \\
\hline
\end{tabular}

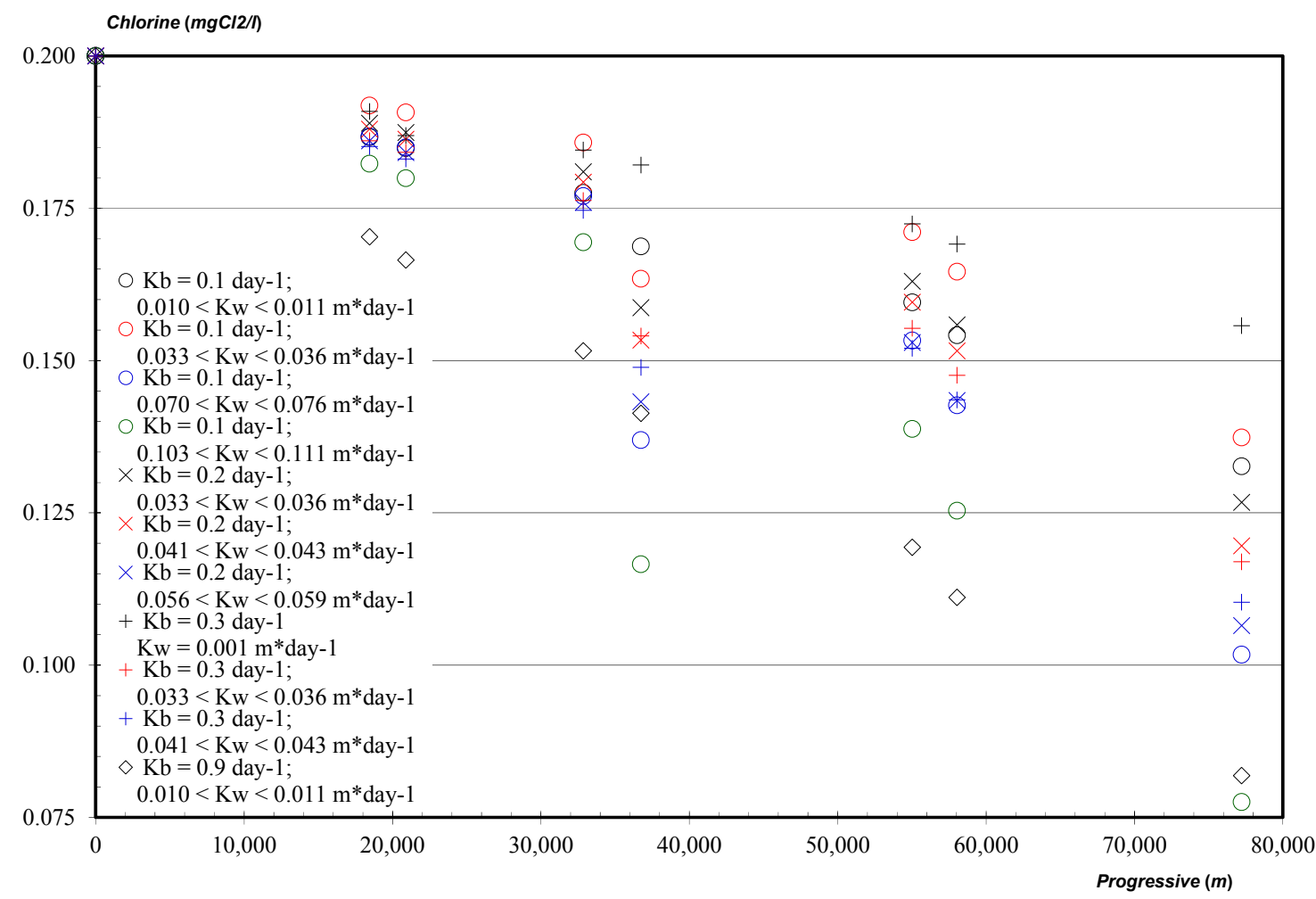

Figure 5. Values of chlorine calculated by the model.

The diagram is constructed by putting the values of the hydraulic residence time in the network, and the chlorine concentration on the abscissa axis and on the ordinate axis, respectively. 
Further evidence for the good fit in terms of agreement between the observed and calculated data can also be observed in Figure 6.

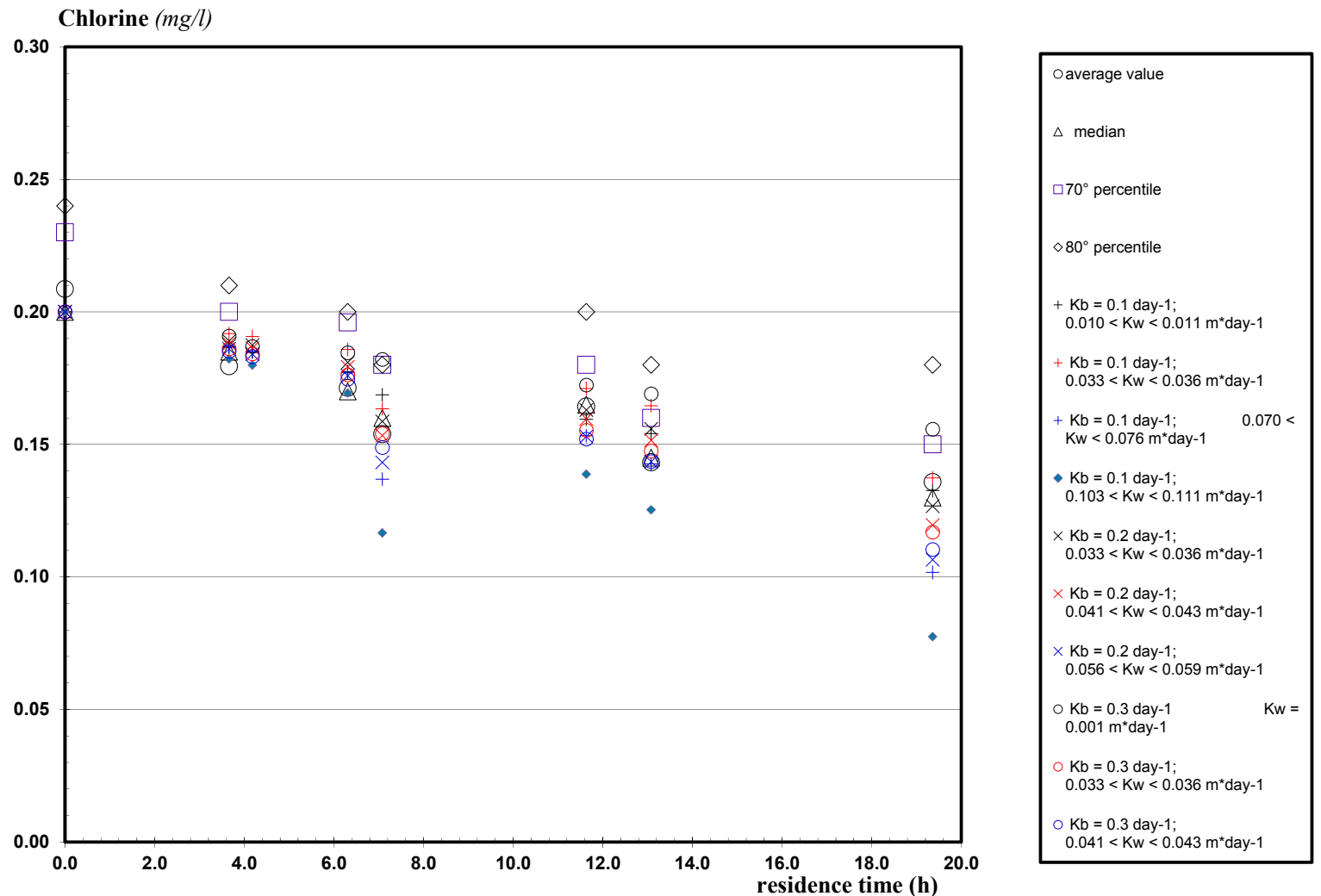

Figure 6. Comparison between calculated values and statistical parameters of the observed data.

\subsection{Discussion}

In more than $70 \%$ of the observed data from the seven selected stations, the processing of the observed aforementioned data showed that, in the period of investigation, the concentration values were below $0.2 \mathrm{mgCl}_{2} / \mathrm{L}$, which is the recommended minimum value at the delivery point to the user, according to the current regulations. Furthermore, the distribution of the average values of the concentration of free chlorine showed a decreasing trend with increasing distance from the disinfection section. A similar trend is observed for other statistical parameters such as the median and the 70th percentile. The consumption of free chlorine in the network can be attributed to the degradation phenomena which occurred periodically under certain conditions for one of the water supply sources. This kind of condition cannot affect a judgment of potability and involves the need to implement a new chlorination phase in the basins of municipal and cooperative utilities in order to reach compliance with the value indicated in the current legislation. The reduction of free chlorine is evident in the pipes closest to the origin of the aqueduct and in the pipes with smaller diameters characterized by more extended running times.

In the first case, such a situation can be attributed to the presence of substances which are rapidly oxidized and therefore consume chlorine. This means that the chlorine demand has not been covered adequately. In the second case, the phenomenon is certainly due to local conditions.

The applied calculation model EPANET showed a good ability to represent the processes of quality degradation in the pipes working in hydraulic stationary conditions. In particular, the constant rate of consumption in the liquid medium, $\mathrm{k}_{\mathrm{b}}$, and the constant rate of chlorine consumption at the solid-liquid contact with the pipeline walls, $\mathrm{k}_{\mathrm{w}}$, were estimated. The simulation results showed very good agreement with the experimental data, with $k_{b}$ values varying between 0.1 and 0.3 day ${ }^{-1}$ 
combined with values of $k_{\mathrm{w}}$ varying between 0.01 and $0.07 \mathrm{~m}_{\text {day }}{ }^{-1}$. These values determined for the examined water networks are lower than those indicated in the technical literature referring to the distribution networks. This consideration demonstrates that in most cases the unfolding of the phenomena of the consumption of free chlorine in water results less intense. This final consideration makes it even more evident how important the issue is, especially with the aim of preserving public health. Obviously, the obtained results should be verified in other detection campaigns and the application should be repeated in other similar contexts.

\section{Concluding Remarks}

From the results of the present study, certain conclusions can be drawn:

- In more than $70 \%$ of the observed data the concentration values were below $0.2 \mathrm{mgCl} / 2 / \mathrm{L}$.

- The reduction of free chlorine is evident in the pipes closest to the origin of the aqueduct and in the pipes with smaller diameters characterized by more extended running times.

- The applied calculation model EPANET showed a good ability to represent the processes of quality degradation in the pipes working in hydraulic stationary conditions.

- $\quad \mathrm{k}_{\mathrm{b}}$ values varied between 0.1 and 0.3 day $^{-1}$ and $\mathrm{k}_{\mathrm{w}}$ varied between 0.01 and $0.07 \mathrm{~m}_{\text {day }}{ }^{-1}$.

- The experience should be repeated in other similar contexts, with future studies also trying to use some additional key parameters, in order to test the generalizability of this study's findings to other similar situations.

Acknowledgments: Special thanks to our friend Ettore, not only for his fundamental contribution to this work, but above all for having honored us with his great friendship. You will always be with us. The work was supported by the Act 211 of the Russian Federation Government, contract No. 02.A03.21.0006.

Conflicts of Interest: The authors declare no conflict of interest.

\section{References}

1. Storey, M.V.; van der Gaag, B.; Burns, B.P. Advances in on-line drinking water quality monitoring and early warning systems. Water Res. 2011, 45, 741-747. [CrossRef] [PubMed]

2. Katsoyiannis, I.A.; Gkotsis, P.; Castellana, M.; Cartechini, F.; Zouboulis, A.I. Production of demineralized water for use in thermal power stations by advanced treatment of secondary wastewater effluent. J. Environ. Manag. 2017, 190, 132-139. [CrossRef] [PubMed]

3. Hua, R.; Zhang, Y. Assessment of water quality improvements using the hydrodynamic simulation approach in regulated cascade reservoirs: A Case Study of drinking water sources of Shenzhen, China. Water 2017, 9, 825. [CrossRef]

4. Yang, Y.J.; Haught, R.C.; Goodrich, J.A. Real-time contaminant detection and classification in a drinking water pipe using conventional water quality sensors: Techniques and experimental results. J. Environ. Manag. 2009, 90, 2494-2506. [CrossRef] [PubMed]

5. Maslia, M.L.; Aral, M.M.; Ruckart, P.Z.; Bove, F.J. Reconstructing historical VOC concentrations in drinking water for epidemiological studies at a U.S. military base: Summary of results. Water 2017, 8, 452.

6. Hall, J.; Zaffiro, A.; Marx, R.; Kefauver, P.; Krishnan, E.; Haught, R.; Herrmann, J. On-line water quality parameters as indicators of distribution system contamination. Am. Water Works Assoc. 2007, 99, 66-77.

7. Sadiq, R.; Rodrssiguez, M.J. Disinfection byproducts (DBPs) in drinking water and predictive models for their occurrence: A review. Sci. Total Environ. 2004, 321, 21-46. [CrossRef] [PubMed]

8. Łangowski, R.; Brdys, M.A. An Interval Estimator for Chlorine Monitoring in Drinking Water Distribution Systems under Uncertain System Dynamics, Inputs and Chlorine Concentration Measurement Errors. Int. J. Appl. Math. Comput. Sci. 2017, 27, 309-322. [CrossRef]

9. Szabo, J.; Hall, J. On-line Water Quality Monitoring for Drinking Water Contamination. Compr. Water Qual. Purif. 2013, 2, 266-282.

10. Munavalli, G.R.; Mohan Kumar, M.S. Water quality parameter estimation in a distribution system under dynamic state. Water Res. 2005, 39, 4287-4298. [CrossRef] [PubMed] 
11. Torretta, V. Environmental and economic aspects of water kiosks: Case study of a medium-sized Italian town. Waste Manag. 2013, 33, 1057-1063. [CrossRef] [PubMed]

12. Tchobanoglous, G.; Schroeder, E.D. Water Quality; Addison-Wesley Publishing Company: Boston, MA, USA, 1992; p. 768.

13. Hua, F.; West, J.R.; Barker, R.A.; Forster, C.F. Modelling of chlorine decay in municipal water supplies. Water Res. 1999, 33, 2735-2746. [CrossRef]

14. Powell, J.C.; Hallam, N.B.; West, G.R.; Forster, C.F.; Simms, J. Factors which control bulk chlorine decay rates. Water Res. 2000, 34, 117-126. [CrossRef]

15. Berry, D.; Xi, C.; Raskin, L. Microbial ecology of drinking water distribution systems. Curr. Opin. Biotechnol. 2006, 17, 297-302. [CrossRef] [PubMed]

16. Frateur, I.; Deslouis, C.; Kiene, L.; Levy, Y.; Tribollet, B. Free chlorine consumption induced by cast iron corrosion in drinking water distribution systems. Water Res. 1999, 33, 1781-1790. [CrossRef]

17. Wang, H.; Masters, S.; Edwards, M.A.; Falkinham, J.O.; Pruden, A. Effect of disinfectant, water age, and pipe materials on bacterial and eukaryotic community structure in drinking water biofilm. Environ. Sci. Technol. 2014, 48, 1426-1435. [CrossRef] [PubMed]

18. Noma, Y.; Yamane, S.; Kida, A. Adsorbable organic halides (AOX), AOX formation potential, and PCDDs/DFs in landfill leachate and their removal in water treatment processes. J. Mater. Cycles Waste Manag. 2001, 3, 126-134.

19. Katsoyiannis, I.A.; Hug, S.J.; Ammann, A.; Zikoudi, A.; Hatziliontos, C. Arsenic speciation and uranium concentrations in drinking water supply wells in Northern Greece: Correlations with redox indicative parameters and implications for groundwater treatment. Sci. Total Environ. 2007, 383, 128-140. [CrossRef] [PubMed]

20. Katsoyiannis, I.A.; Zouboulis, A.I. Use of iron- and manganese-oxidizing bacteria for the combined removal of iron, manganese and arsenic from contaminated groundwater. Water Qual. Res. J. Can. 2006, 41, 117-129.

21. Proctor, C.R.; Hammes, F. Drinking water microbiology-from measurement to management. Curr. Opin. Biotechnol. 2015, 33, 87-94. [CrossRef] [PubMed]

22. Lu, W.; Kiene, L.; Levi, Y. Chlorine demand of biofilms in water distribution systems. Water Res. 1999, 33, 827-835. [CrossRef]

23. Douterelo, I.; Boxall, J.B.; Deines, P.; Sekar, R.; Fish, K.E.; Biggs, C.A. Methodological approaches for studying the microbial ecology of drinking water distribution systems. Water Res. 2014, 65, 134-156. [CrossRef] [PubMed]

24. Niquette, P.; Servais, P.; Savoir, R. Impacts of pipe material on densities of fixed bacterial biomass in a drinking water distribution system. Water Res. 2000, 34, 1952-1956. [CrossRef]

25. Volterra, L. Presenza e sopravvivenza di varie forme biologiche in acqua di rete (Presence and survival of various biological forms in the water network). Ambient. Risorse Salut. 1994, 3, 23-30.

26. Servais, I.; Anzil, A.; Ventresque, C. Simple Method for Determination of Biodegradable Dissolved Organic Carbon in Water. Appl. Environ. Microbiol. 1989, 55, 2732-2734. [PubMed]

27. Servais, P.; Billen, G.; Laurent, P.; Levi, Y.; Randon, G. Studies of BDOC and bacterial dynamics in the drinking water distribution system of the Northern Parisian suburbs. J. Water Sci. 1992, 5, 69-89. [CrossRef]

28. Kaplan, L.A.; Reasoner, D.J.; Rice, E.W. A survey of BOM in U.S. drinking waters. Am. Water Works Assoc. 1994, 86, 121-132.

29. Elshobargy, W.E.; Abu-Qdais, H.; Elsheamy, M.K. Simulation of THM species in water distribution systems. Water Res. 2000, 34, 3431-3439.

30. Foxon, T.J.; McIlkenny, G.; Gilmour, D.; Oltean-Dumbrava, C.; Souter, N.; Ashley, R.; Butler, D.; Moir, J. Sustainability criteria for decision support in the UK water industry. J. Environ. Plan. Manag. 2002, 45, 285-301. [CrossRef]

31. Kalbar, P.P.; Karmakar, S.; Asolekar, S.R. Selection of an appropriate wastewater treatment technology: A scenario-based multiple-attribute decision-making approach. J. Environ. Manag. 2012, 113, 158-169. [CrossRef] [PubMed]

32. Torretta, V. The sustainable use of water resources: A technical support for planning. A case study. Sustainability 2014, 6, 8128-8148. [CrossRef]

33. Trulli, E.; Torretta, V.; Rada, E.C.; Istrate, I.A.; Papa, E.A. Modelling for use of water in agriculture. Agric. Eng. 2014, 44, 121-128. 
34. Aydin, N.Y.; Zeckzer, D.; Hagen, H.; Schmitt, T. A decision support system for the technical sustainability assessment of water distribution systems. Environ. Model. Softw. 2015, 67, 31-42. [CrossRef]

35. Rossman, L.A. Epanet 2, User's Manual; EPA/600/R-00/057, September 2000; Water Supply and Water Resources Division, National Risk Management Researh Laboratory, Office of Research and Development, U.S. Environtal Protection Agency: Cincinnati, OH, USA, 2000.

36. Rossman, L.A.; Boulos, P.F. Numerical methods for modeling water quality in distribution systems: A comparison. J. Water Res. Plan. Manag. 1996, 122, 137-146. [CrossRef]

37. Ohara, Z.; Ostfelda, A.; Lahava, O.; Birnhacka, L. Modelling heavy metal contamination events in water distribution systems. Procedia Eng. 2015, 119, 328-336. [CrossRef]

38. Kiene, L.; Lu, W.; Levi, Y. Relative importance of the phenomena responsible for chlorine decay in drinking water distribution systems. Water Sci. Technol. 1998, 38, 219-227.

39. Zhu, Z.; Wu, C.; Zhong, D.; Yuan, Y.; Shan, L.; Zhang, J. Effects of pipe materials on chlorine-resistant biofilm formation under long-term high chlorine level. Appl. Biochem. Biotechnol. 2014, 173, 1564-1578. [CrossRef] [PubMed]

40. Notter, R.H.; Sleicher, C.A. The eddy diffusivity in the turbulent boundary layer near a wall. Chem. Eng. Sci. 1971, 26, 161-171. [CrossRef]

41. UNICHIM. Metodologie di Analisi Delle Acque (Water Analysis Methodology) 2014. Available online: http:/ / www.unichim.it/index.php?n=Pubblicazioni.MetodiAcque (accessed on 3 November 2017).

42. Douterelo, I.; Sharpe, R.L.; Boxall, J.B. Influence of hydraulic regimes on bacterial community structure and composition in an experimental drinking water distribution system. Water Res. 2013, 47, 503-516. [CrossRef] [PubMed]

43. Olyaie, E.; Banejad, H.; Chau, K.-W.; Melesse, A.M. A comparison of various artificial intelligence approaches performance for estimating suspended sediment load of river systems: A case study in United States. Environ. Monit. Assess. 2015, 187, 189. [CrossRef] [PubMed]

44. Wang, W.C.; Xu, D.M.; Chau, K.-W.; Lei, G.J. Assessment of river water quality based on theory of variable fuzzy sets and fuzzy binary comparison method. Water Res. Manag. 2014, 28, 4183-4200. [CrossRef]

(C) 2018 by the authors. Licensee MDPI, Basel, Switzerland. This article is an open access article distributed under the terms and conditions of the Creative Commons Attribution (CC BY) license (http:/ / creativecommons.org/licenses/by/4.0/). 